\title{
The Recurring Question of the "Limited" Constitutional Convention
}

\author{
Walter E. Dellinger ${ }^{\dagger}$
}

Article V of the United States Constitution requires Congress to call "a Convention for proposing Amendments" upon application of two-thirds of the states. ${ }^{1}$ Amendments proposed by such a convention, if subsequently ratified by three-fourths of the states, become part of the Constitution. Thus far in the history of the republic, no such convention has been called. In the last few years, however, thirty states ${ }^{2}$ have submitted applications to Congress calling for a convention restricted to consideration of an amendment requiring a balanced federal budget. Only four more applications are necessary to reach the total of twothirds specified by Article V; Congress is said to have been brought "to the brink of calling a constitutional convention."3

For a century following the Constitutional Convention in 1787, the only applications submitted by state legislatures under Article $V$ contemplated conventions that would be free to determine their own agendas. ${ }^{4}$ Only in this century have legislatures begun to submit ap-

$\dagger$ Professor of Law, Duke University.

1. Article V reads as follows:

The Congress, whenever two thirds of both Houses shall deem it necessary, shall propose Amendments to this Constitution, or on the Application of the Legislatures of two thirds of the several States, shall call a Convention for proposing Amendments, which, in either Case, shall be valid to all Intents and Purposes, as Part of this Constitution, when ratified by the Legislatures of three fourths of the several States, or by Conventions in three fourths thereof, as the one or the other Mode of Ratification may be proposed by the Congress; Provided that . . . no State, without its Consent, shall be deprived of its equal Suffrage in the Senate.

2. As of May 31, 1979, twenty-nine of these state resolutions had been printed in the Congressional Record: 125 CoNG. REc. 56085 (daily ed. May 16, 1979) (New Hampshire); id. at $S 5017$ (daily ed. May 1, 1979) (Indiana); id. at $\$ 2363$ (daily ed. Mar. 8, 1979) (Arkansas and Utah); id. at S193I (daily ed. Mar. 1, 1979) (South Dakota); id. at S1932 (Idaho); id. at S1306 (daily ed. Feb. 8, 1979) (Alabama, Arizona, and Colorado); id. at S1307 (Delaware, Florida, Georgia, Kansas, and Louisiana); $i d$. at S1308 (Maryland and Mississippi); id. at S1309 (Nebraska and Nevada); id. at S1310 (New Mexico, North Dakota, Oklahoma, and Oregon); id. at S1311 (Pennsylvania and South Carolina); id. at 51312 (Tennessee, Texas, and Virginia); id. at $S 1313$ (Wyoming); id. at S1123 (daily ed. Feb. 6, 1979) (North Carolina). As of May 31, 1979, the resolution by Iowa, S. J. Res. 1 (1979), had not been printed in the Congressional Record. For a discussion of the validity of these applications, see p. 1636 infra.

3. National Law Journal, Mar. 5, 1979, at 1, col. 2.

4. See Black, Amending the Constitution: $A$ Letter to a Congressman, 82 YALE L.J. 189, 202-03 (1972). 
plications reflecting a different view. These applications are premised upon three assumptions: (1) Congress may limit in advance the subject matter authority of any convention called for proposing amendments; (2) it is valid for states to specify in their applications that the convention be formally limited; and (3) Congress, in response to these requests for a "limited subject matter" convention, must call a limited convention, define the scope of the matters that may be considered in accordance with the state applications, and require that the convention stay within those limits. ${ }^{5}$

This article, however, argues that any new constitutional convention must have authority to study, debate, and submit to the states for ratification whatever amendments it considers appropriate. Although such a convention might well decide to focus upon one issue, it cannot be required to do so by Congress or the state legislatures. This article also concludes that any state convention applications that are premised on the erroneous view that a convention can be limited in advance must be treated by Congress as invalid.

\section{Evolution of Article V at the Philadelphia Convention}

An examination of the debates over Article $\mathrm{V}$ at the Philadelphia Convention establishes that the framers were concerned about the role constitutional amendments might play in the allocation of power between the state legislatures and the federal government. An analysis of the evolution of Article $V$ illuminates the framers' intentions with respect to the role constitutional conventions should play, and supports the conclusion that the subject matter of such conventions cannot be limited.

The delegates in Philadelphia generally agreed that provision should

5. The most insightful piece supporting the state legislatures' position is a recent article by Professor William Van Alstyne, Does Article V Restrict the States to Calling Unlimited Conventions Only?-A Letter to a Colleague, 1978 DukE L.J. 1295. For earlier arguments supporting the position that mandatory limits can be imposed on a convention, see Rhodes, $A$ Limited Federal Constitutional Convention, 26 U. FLA. L. REv. I (1973); Bonfield, The Dirksen Amendment and The Article $V$ Convention Process, 66 Mich. L. Rev. 949 (1968); Note, Proposed Legislation on the Convention Method of Amending the United States Constitution, 85 HARv. L. REv. 1612, 1629 (1972). Other arguments defending the validity of limited applications are included in Memorandum from $\mathrm{J}$. Anthony Kline, Legal Affairs Secretary, to Edmund G. Brown, Jr., Governor of California (Jan. 31, 1979) (on file with Yale Law Journal) [hereinafter cited as California Memorandum]; Special Constitutional Convention Study Comm., American Bar Assoc., Amendment of the Constitution by the Convention Method Under Article V (1974) [hereinafter cited as ABA REPORT].

Professor Charles Black has been the leading advocate of the view that Article $V$ conventions cannot be limited in scope by either Congress or the state legislatures and that state requests for the limited convention are invalid. See Black, supra note 4, at 189. 


\section{Limited Conventions}

be made for amendment of the new Constitution. Experience under the Articles of Confederation, which provided that a single state could veto amendments, ${ }^{6}$ persuaded the delegates of the need for an easier revision process. But it also was understood that casual or frequent amendment would threaten both the stability of the new government and the delicate balance of compromises hammered out at the first Convention.

The Philadelphia Convention readily agreed upon a method for ratifying proposed amendments to the new Constitution. After considering motions to require unanimous ratification by the states, or ratification by two-thirds, the Convention decided that approval by three-fourths of the states should be necessary in order to ratify amendments. ${ }^{7}$ But a critical question remained: who should propose amendments? What organ of government should be empowered to initiate, develop and submit amendments for ratification? It proved particularly difficult to decide whether Congress should have the power to veto amendments the state legislatures wished to submit for ratification. The resolution chosen by the delegates midway through the deliberations was a grant of concurrent power to Congress and the state legislatures to initiate the amendment process. The Convention easily agreed on the method by which Congress would propose amendments, ${ }^{8}$ and debate centered upon the alternative mode. Mason of Virginia objected to congressional control over the proposal of amendments because congressional abuses of power might be the cause of the perceived need for reform. ${ }^{9}$ Set against this concern was the threat, perceived by Hamilton, that the states would seek amendment to enhance their power at the expense of the federal government. ${ }^{10}$ This debate reflected the tension felt throughout the entire Convention between the need to create an effective national structure, significantly stronger than the one existing under the Articles of Confederation, and the desire to guard against delegating excessive power to the central government.

The drafters' answer to this dilemma was to provide that a national

6. Art. XIII of the Articles of Confederation provided that "[no] alteration [shall] at any time hereafter be made in [these Articles ....] unless such alteration be agreed to in a Congress of the United States, and be afterwards confirmed by the Legislatures of every State." U.S.C. xxxv, xxxviii (1976).

7. II The Records of the Federal Convention of 1787, at 555 (M. Farrand ed. 1937) [hereinafter cited without cross-reference as II FARRAND].

8. II FARRAND at 559. This provision was not discussed or altered in later debates on Article V.

9. I The Records of the Federal Conventron of 1787, at 202-03 (M. Farrand ed. 1937) [hereinafter cited without cross-reference as I FARRAND].

10. II FARRAND at 558. 
convention to propose amendments be summoned at the request of two-thirds of the state legislatures. ${ }^{11}$ Such a convention would be, like Congress, a deliberative body with a national perspective, capable of assessing the need for constitutional change as well as developing proposals to be submitted for ratification; yet it would not be Congress itself. Thus the convention mode of amendment would avoid both the problem of congressional obstruction of needed reforms and the problem posed by parochial state self-interest.

The debates of the Philadelphia Convention trace the evolution of the delegates' decision to adopt a convention mode. The Virginia Resolutions, presented at the outset of the Convention by Edmund Randolph, made the first mention of the need to provide for amendments and reflected Randolph's concern over the danger of congressional control of the amendment process. The Thirteenth Virginia Resolve, introduced on May 29, 1787, stated "that provision ought to be made for the amendment of the Articles of Union whensoever it shall seem necessary, and that the assent of the National Legislature ought not to be required thereto." 12 Although some delegates did not see the necessity of providing for amendment at all, ${ }^{13}$ the principal issue, according to Madison's notes, was "the propriety of making the consent of the Natl. Legisl. unnecessary."14 Randolph and Mason of Virginia defended the part of the resolution that made congressional assent unnecessary. ${ }^{15}$ The delegates were divided on the issue, however, and the Convention voted to postpone consideration of that part of the resolution..$^{16}$

When the Convention next addressed the resolution, the controversial portion had been removed; Randolph's new Seventeenth Virginia Resolve simply read, "Resolved that provision ought to be made

11. In the latter part of the eighteenth century, conventions rather than legislatures were considered to be the institutions that most nearly embodied popular sovereignty. See generally G. WoOd, The Creation of The AmErican Republic, 1776-1787, at 306.43 (1969). With regard to the decision to ratify the Constitution by convention in each state, Professor Herman Ames wrote, "This was in harmony with the prevailing theory of the age, namely, that the sovereign people spoke directly through a convention elected for a specific purpose." Ames, Recent Development of the Amending Power as Applied to the Federal Constitution, 72 Proc. Am. Philosophical Soc. 87, 92 (1933).

12. I The Documentary History of the Ratification of the Constitution 245 (M. Jensen ed. 1976) [hereinafter cited without cross-reference as I DocuMENTARY HIsTORY].

13. I FARRAND at 202.

14. Id.

15. See id. at 203 (statement of Mason) ("It would be improper to require the consent of the Natl. Legislature, because they may abuse their power, and refuse their consent on that very account. The opportunity for such an abuse, may be the fault of the Constitution calling for amendmt.")

16. Id. 


\section{Limited Conventions}

for the amendment of the articles of Union, whensoever it shall seem necessary." 17 The resolution did not specify methods for either proposal or ratification of amendments. The Convention submitted it in this ambiguous form to the Committee of Detail on July 24.18 When a draft constitution emerged from the Committee of Detail on August 6, the Nineteenth Article stated, "On the application of the Legislatures of two thirds of the States in the Union, for an amendment of this Constitution, the Legislature of the United States shall call a Convention for that purpose."19 It is not clear whether this draft contemplated that the states could apply for a convention specifically limited to consideration of a particular amendment to the Constitution, or whether the provision contemplated conventions with authority to provide generally for the revision and amendment of the Constitution..$^{20} \mathrm{~A}$ more serious defect was the article's failure to specify any method of ratification.

Although the Convention approved the draft Article on August 30,21 Elbridge Gerry of Massachusetts moved to reconsider it on September 10.22 Gerry was troubled that a convention apparently could amend the Constitution without any further requirement of ratification. $\mathrm{He}$ feared that a majority at a convention could "bind the Union to innovations that may subvert the State-Constitutions altogether." ${ }^{23}$ His motion was seconded by Hamilton, who "did not object to the consequences stated by Mr. Gerry," ${ }^{24}$ but opposed the Article for different reasons. Hamilton warned that " $[\mathrm{t}]$ he State Legislatures will not apply for alterations but with a view to increase their own powers. . ."25 Hamilton suggested that the national legislature be authorized to call a constitutional convention upon the affirmative vote of two-thirds of both Houses. Roger Sherman proposed an amendment providing for the national legislature to propose amendments without a convention. ${ }^{26}$

17. I DOCUMENTARY Histokiy at 250.

18. Id. at $255,259$.

19. Id. at 269.

20. The $A B A$ Report underscores the phrase "an amendment" in quoting this draft, presumably to suggest that the draft contemplated that state legislatures would apply for conventions to propose single amendments to the Constitution. ABA REPORT, supra note 5 , at 12. The phrase used in the draft, however, is not "an amendment to" the Constitution, but rather "an amendment of" the Constitution. The more natural reading is that this phrase is used in the sense of "a revision of" the Constitution.

21. II FARRAND at $467-68$.

22. Id. at 557 .

23. Id. at 557-58.

24. Id. at 558 .

25. $I d$.

26. Id. 
Madison then offered the substitute draft that provided the structure and substance of what eventually became Article V. It read:

The Legislature of the U.S. whenever two thirds of both Houses shall deem necessary, or on the application of two thirds of the Legislatures of the several States, shall propose amendments to this Constitution which shall be valid to all intents and purposes as part thereof, when the same shall have been ratified by three fourths at least of the Legislatures of the several States, or by Conventions in three fourths thereof, as one or the other mode of ratification may be proposed by the Legislatures of the U.S.27

The Convention tentatively adopted Madison's proposal by a vote of nine states in favor, one against, one divided. The Madison draft did not provide for any convention method of proposing amendments; Congress was to propose amendments "whenever two thirds of both Houses shall deem necessary" or "on the application of two thirds of the Legislatures of the several States." The article was submitted to the Committee of Style, ${ }^{28}$ which returned it several days later with only minor stylistic changes. ${ }^{29}$

On September 15, the Article was reconsidered by the Convention. Debate centered on the section of the Madison draft that provided that state legislatures could propose amendments, which Congress would submit for state ratification. ${ }^{30}$ Since the draft gave authority to Congress to propose amendments on its own initiative, it would seem to follow that the provision permitting states to apply to Congress to "propose amendments" would allow them to suggest the content of those amendments. Thus, the most plausible reading of the Madison proposal is that it would have permitted two-thirds of the state legislatures to propose amendments to the Constitution; Congress would merely transmit those amendments to be ratified.

The Constitutional Convention rejected that provision in Madison's draft. On the motion of Gouverneur Morris and Elbridge Gerry, the Convention voted without dissent to substitute language requiring Congress to call a constitutional convention on the application of twothirds of the state legislatures. ${ }^{31}$ This accomplished the following change in Article V: "The Congress, whenever two-thirds of both houses shall deem it necessary, shall propose Amendments to this Consti-

27. Id. at 559 .

28. I DOCUMENTARY History, at 270, 283.

29. II FARRAND, at 629.

30. Id. at $629-30$.

31. Id. 


\section{Limited Conventions}

tution, or on the application the legislatures of two thirds of the several states, shall proposements tion, call a Convention for proposing Amendments, ....."32

The accompanying discussion at the Convention does not clearly reveal the basis for the changes. Under Madison's draft, there was no guarantee that a national forum would be involved in the drafting of amendment proposals. Roger Sherman, one of the two recorded speakers, expressed "fears" in reference to the unamended Madison proposal "that three fourths of the States might be brought to do things fatal to particular States, as abolishing them altogether or depriving them of their equality in the Senate." 33 The Morris-Gerry motion might be seen as responsive to Sherman's concern, ${ }^{34}$ for it provided that a national convention, rather than the states, would formulate proposed amendments.

Mason of Virginia expressed a different-indeed, almost oppositeobjection to the Madison draft. ${ }^{35}$ In his opinion, the draft did not impose a mandatory duty upon Congress to submit the state legislatures' suggested amendments for ratification. Instead, he read it as giving Congress either discretion to withhold the suggested amendments or considerable influence in the drafting of the amendments. This plan was "exceptionable \& dangerous" in Mason's view:

As the proposing of amendments is in both the modes to depend, in the first immediately, and in the second, ultimately, on Congress, no amendments of the proper kind would ever be obtained by the people, if the Government should become oppressive, as he verily believed would be the case. ${ }^{36}$

Though this seems a curious objection, given the seemingly mandatory language of the Madison draft, ${ }^{37}$ it may have been based on Mason's

32. I Documentary History at 284, 295. (The parts of the Article submitted to the Convention by the Committee of Style and left unchanged are in roman type; the deletions by the Convention are in lined-out type; changes made by the Convention are in italics; stylistic changes are not reflected here.)

33. II FARRAND at 629 .

34. It is possible that Sherman's objection might have been directed not at the allocation of authority to propose amendments, but rather at the lack of substantive limits on the amending power. These objections were partially met by the subsequent action of the delegates in adding a provision to Article $\mathrm{V}$ whereby no state could, without its consent, be deprived of its equal suffrage in the Senate.

35. II Farrand at 629 .

36. Id.

37. Madison could not understand this objection in light of the delegates' clear expectation that Congress would call a convention in response to state applications: "Mr. Madison did not see why Congress would not be as much bound to propose amendments applied for by two thirds of the States as to call a Convention on the like application." II FARRAND at 629-30. 
belief in the practical necessity of having a single deliberative body undertake the consultation, debate, drafting, compromise, and revision necessary to produce an amendment.

Mason may have supposed that Congress, during the process of proposing amendments in response to a variety of state applications, would exercise great influence on the shape and substance of the amendments. The Morris-Gerry alternative convention mode, however, could be read as imposing a ministerial duty on Congress but not involving it in shaping amendments. Mason as well as the other delegates could thus support the requirement that Congress call a convention upon application by the states as a plan that realistically limited the duty imposed upon Congress, while leaving the determination of the subject matter and the drafting of any amendments to the convention itself. ${ }^{38}$

\section{Controlling the Agenda of Constitutional Conventions}

The accounts of the Philadelphia Convention do not expressly answer the question of whether a convention can be limited by either the states or by Congress. Two themes, however, do emerge from the debates: Congress should not have exclusive power to propose amendments; and state legislatures should not be able to propose and ratify amendments that enhance their power at the expense of the national government. States were empowered under Article V to ratify amendments; the power to propose amendments was lodged in two national bodies, Congress and a convention. The proceedings suggest that the framers did not want to permit enactment of amendments by a process of state proposal followed by state ratification without the substantive involvement of a national forum. Permitting the states to limit the subject matter of a constitutional convention would be inconsistent with this aim. If the state legislatures could not only control the text of the proposed amendment, but also limit the convention to that subject, effective proposal power would have been shifted to the state legislatures. If the states could confine the convention to a general

38. Such a view of Article $V$ is expressed in the first state application for a constitutional convention, submitted by Virginia in 1787 :

We do, therefore, in behalf of our constituents, in the most earnest and solemn manner, make this application to Congress, that a convention be immediately called, of deputies from the several States, with full power to take into their consideration the defects of this Constitution that have been suggested by the State Conventions, and report such amendments thereto as they shall find best suited to promote our common interests, and secure to ourselves and our latest posterity the great and unalienable rights of mankind.

I ANNAls of Congress at col. 259-60 (Gales \& Seaton eds. 1834) (emphasis added). 


\section{Limited Conventions}

subject, but not to a specific amendment, and the applying legislatures suggested different limitations, then Congress would be forced to define and enforce limits on the convention. Such action would conflict with a different aim of the drafters: the desire to create a mode of proposing amendments in which Congress played no significant role. In order to satisfy the various objectives of the framers, a convention must be free to define for itself the subject matter it will address; the state legislatures may call for such a convention, but they should not be permitted to control it.

\section{A. Conventions Limited to a Single Amendment}

The most stringent limitation upon a convention would be a congressional requirement that it consider only a draft amendment, the wording of which had been ordained in advance by the applying state legislatures. One example of this kind of limitation is found in Delaware's 1975 application to Congress "to call a convention for the proposing of the following amendment to the Constitution of the United States: ... The costs of operating the Federal Government shall not exceed its income during any fiscal year, except in the event of declared war." 30 The Delaware application makes clear the state's desire to limit the convention to consideration of this amendment. The application expressly states that

the General Assembly of the State of Delaware interprets Article $\mathrm{V}$ to mean that if two-thirds of the states make application for a convention to propose an identical amendment to the Constitution for ratification with a limitation that such amendment be the only matter before it, that such convention would have power only to propose the specified amendment and would be limited to such proposal and would not have power to vary the text therof nor would it have power to propose other amendments on the same or different propositions. ${ }^{40}$

Professor Van Alstyne, an advocate of the view that state-imposed limitations on the authority of conventions are constitutionally permissible, has argued that

Congress could least decline to call a convention if, in keeping with [thirty-four resolutions such as Delaware's] the sole function of that convention would be to do no more than to deliberate and

39. Del. H. Con. Res. No. 36 (1975), reprinted in 125 CoNG. REc. S1307 (daily ed. Feb. 8, 1979).

40. Id. (emphasis added). 
to debate the pros and cons of an exactly particularized proposal, with choice at the convention's conclusion for the delegates only to vote 'yea' or 'nay.' ${ }^{11}$

He argues that the framers intended the states to have a ready means of curing defects that Congress would not address, and suggests that

[i]f two-thirds of the state legislatures might perchance agree on the exact wording of an amendment they would wish to be reviewed in a called convention for discussion and vote, this would seem to me to state the paradigm case in which Congress should proceed with the call-and limit the agenda exactly in accordance with the unequivocal expressions of those solely responsible for the event. ${ }^{42}$

This approach, though it provides a means of proposing amendments that is free of congressional control, is not responsive to the second aim of the Philadelphia Convention; state legislatures should not be given authority to propose amendments without the involvement of some national body in the formulation of such amendments. To permit the state legislatures to dictate to the convention the exact terms of its proposals is to short-circuit the carefully structured division of authority between state and national interests.

If the aim had been to give the state legislatures the power to propose as well as to ratify amendments, it would have been unnecessary to provide for conventions. The drafters could simply have provided that when two-thirds of the state legislatures agree on the wording of an amendment, some central authority must automatically submit that amendment for ratification by the required three-fourths of the states. Of course, a convention whose sole authority would be to vote "yes" or "no" on a proposal dictated in advance by state legislatures could, by delaying the amendment process, serve an important function by allowing time for reflection and debate and by providing an additional hurdle for any proposed amendment. Assembling a tightly controlled convention for this limited purpose, however, would have made little sense to the drafters in 1787 . The difficulty of choosing and assembling delegates from all the states was extraordinary; commencement of national meetings was sometimes delayed for weeks by the late arrival of many of the delegates. ${ }^{43}$ Delegates to such a convention would likely

41. Van Alstyne, supra note 5 , at 1305 .

42. Id. at 1305.06 .

43. See M. Farrand, The Framing of the Constitution of the United States 54 (1913) (Constitutional Convention called to meet on May 14,1787, but "[p]artly owing to the difficulties and slowness of travel ... it was not until Friday, the twenty-fifth of May, that seven states were represented and the convention could proceed to organize.") 


\section{Limited Conventions}

be frustrated by the delay and anxious to get on with the sole official act permitted them: voting on an amendment whose wording had been determined beforehand. The framers understood that "[c]onventions are serious things," 44 and it is doubtful that they meant to suggest such a meeting by the phrase "a Convention for proposing Amendments."

\section{B. Conventions Limited to a Particular Subject}

Even when the applying state legislatures seek only to limit the convention with respect to subject matter, the case against the validity of the applications is still persuasive. Narrowly defined subject matter limits have to a lesser extent the same difficulty as limits that confine a convention to consideration of a specific text: they transfer the proposing power from the convention to the state legislatures. The more restricted the alternatives available to a convention, the greater the chance that any amendment will in effect have been predetermined. ${ }^{45}$ Moreover, restricting the convention's subject matter may have a deleterious effect on the amendment process. The framers knew from their experience in Philadelphia that issues are often fundamentally redefined in the course of their resolution; accommodations in seemingly unrelated areas may permit resolution of complex issues in an unanticipated manner. Narrowly defining in advance the subject matter of a convention would seriously hamper the process of creative compromise that had been central to the success of the Philadelphia Convention.

Although this predetermination argument applies less directly to broader limitations on a convention, other problems arise if only general subject matter limitations are imposed. Such limits differ importantly from "exact text" limitations in that the process of setting the subject matter agenda of a convention is likely to give Congress a significant degree of control over the convention. It is conceivable that thirty-four state legislatures would agree on exactly the same limitation of a convention's subject matter. However, it is more likely that state

44. II FARRAND at 632 (statement of Charles Pinkney).

45. This critical point is overlooked in both the California Memorandum, supra note 5 , and the ABA RePorr, supra note 5. The California Memorandum states:

The notion that the states lack the power to limit a convention is also at war with the principle major continet in se minus; that is, absent an expressed intent to the contrary, a body vested with specified powers inherently possesses and may exercise lesser powers. As stated by the ABA Committee, "since Article V specifically and exclusively vests the state Legislatures with the authority to apply for a convention, we perceive no sound reason as to why they cannot invoke limitations in exercising that authority."

California Memorandum, supra note 5 , at 14 . The difficulty with this argument is its unwarranted assumption that the power to define a convention's agenda and restrict its deliberations is a lesser power than the authority to call the convention. 
applications would vary in both their description of the problem giving rise to the applications, and their suggested revisions. Congress, in framing the call for the convention, would then assume a major role in defining the subject matter. ${ }^{46}$ That role should be left to the convention itself in order to avoid undue congressional influence over the convention mode of amendment. ${ }^{47}$

Proponents of the view that "limited convention" applications are valid also rely on the argument that the convention mode should be free of congressional control. Professor Van Alstyne argues that con-

46. An alternative solution would leave the definition and enforcement of any limits to the judiciary. The courts could enjoin the ratification process on the ground that an amendment proposal was not within the subject matter limits set by the original applications, or could refuse to give effect to the amendment after ratification on the ground that it was beyond the proposing authority of the convention. This alternative would merely substitute judicial control of the convention for congressional control. There is nothing in the deliberations to indicate that the drafters contemplated either congressional or judicial control over the subject matter of a constitutional convention.

47. Consider the example of the Bill of Rights. Several state conventions accompanied ratification of the Constitution with a recommendation that amendments be adopted. Different states proposed different amendments on a variety of subjects. Compare the amendments proposed by virginia, The Debates in the Several State Conventions on the Adoption of the Federal Constitution at Philadelphia in 1787, vol. 3 at 657.63 (J. Elliot ed. 1937) with the proposals by Massachusetts, id., vol. 2 at 176-78. Had these amendments been proposed by convention rather than by Congress, it would have been highly inappropriate for Congress, the body whose powers were to be constrained by a number of the suggested revisions, to attempt to limit the questions to be considered.

It does not appear to have occurred to James Madison that Congress could call a "limited" convention to propose a bill of rights. In a letter written to George Eve on Jan. 2, 1789, Madison expressed his preference, under the circumstances, for the congressional mode of proposing amendments:

The Congress who will be appointed to execute as well as to amend the Government, will probably be careful not to destroy or endanger it. A Convention, on the other hand, meeting in the present ferment of parties, and containing perhaps insidious characters from different parts of America, would at least spread a general alarm, and be but too likely to turn everything into confusion and uncertainty. It is to be observed however that the question concerning a General Convention, will not belong to the federal Legislature. If $2 / 3$ of the States apply for one, Congress cannot refuse to call it; if not, the other mode of amendments must be pursued.

5 The Writings of James Madison 321 (G. Hunt ed. 1904). In a letter to Phillip Mazzei dated December 10, 1788, Madison stated his belief that

The object of the Anti-Federalists is to bring about another general Convention, which would either agree on nothing, as would be agreeable to some, and throw everything into confusion, or expunge from the Constitution parts which are held by its friends to be essential to it.

$I d$. at 316. Madison did not suggest the possibility of countering the drive for a "general convention" by seeking to limit the convention's subject matter authority in advance. See Martin, Madison's Precedent of Legislative Ratification for Constitutional Amendments, 109 Proc. Am. Philosophical Soc. 47, 49-50 (1965).

Two passages in The Federalist, one of them by Madison, have been cited in support of the position that the framers believed "the convention need not be unlimited in scope." Note, supra note 5, at 1629. This argument has been rebutted by Professor Black, see Black, supra note 4 , at 197 , and is further undermined by these passages from Madison's correspondence. 


\section{Limited Conventions}

gressional authority to treat "limited" applications as invalid could be used to obstruct state initiation of constitutional conventions:

the state mode for getting amendments proposed was not to be contingent upon any significant cooperation or discretion in Congress. ... Congress was supposed to be mere clerk of the process convoking state-called conventions. Certainly it was not imagined to sit astride that process as a hostile censor, a body entitled to impose such stringent requirements upon the states as effectively to render the state mode of securing particular amendments nearly impossible. ${ }^{48}$

This point is not without merit. A generous construction by Congress of what constitutes a valid application may be seen as most consistent with the limited role Congress was to perform under the convention mode of amendment. But if Congress is to be "mere clerk of the process," it should leave the influential task of agenda-setting to the convention itself. Moreover, Congress could establish a precedent that applications are valid if and only if applying states understand that the convention will be free to set its own limits. This determination would be significantly less intrusive than if Congress were to undertake with each set of applications to infer and enforce limits on the subject matter authority of the convention. ${ }^{48}$

It is possible that a set of state applications could establish subject matter limitations sufficiently broad to provide latitude for compromise and consensus-building at the convention and sufficiently uniform to enable Congress to define and enforce those limits without

48. Van Alstyne, supra note 5, at 1303.

49. The extent to which Congress could exercise influence over a "limited convention" is suggested by the provisions of the Ervin Bill, which passed the Senate in 1971, S. 215, 92d Cong., 1st Sess., 117 Conc. Rec. 36804-06 (1971), but was not acted upon by the House. The Ervin Bill sought to establish in advance procedures by which a constitutional convention would be called if Congress ever received the requisite number of applications. The bill was thoroughly premised upon a "limited convention" view of Article $\mathrm{V}$ and provided, among other things: that each state resolution should "stat[e] the nature of the amendment or amendments to be proposed," id. at $\$ 2$; that Congress, in calling the convention, should "set forth the nature of the amendment or amendments for the consideration of which the convention is called," id. at $\$ 6(\mathrm{a})$; that "[b]efore taking his seat each delegate shall subscribe to an oath ... to refrain from proposing ... [any] amendment to the Constitution of the United States relating to any subject which is not named ... in the concurrent resolution of the Congress by which the convention was called," id. at $\$ 8(\mathrm{a})$; that "[n]o convention . . . may propose any amendment or amendments of a nature different from that stated in the concurrent resolution [of Congress] calling the convention," id. at $\S 10(\mathrm{~b})$; and that questions concerning whether a proposed amendment is within the limits set by the congressional resolution "shall be determined solely by the Congress of the United States..." id. at § 13(c). 
unduly intruding into the convention's work. ${ }^{50}$ It is more likely, however, that state applications attempting to limit the subject matter of a convention will result in either impermissible state control of the proposal process or undue congressional influence over that process. ${ }^{.1}$ Consequently, while a convention should be influenced in its choice of agenda by the grievances that led the states to apply for its convocation, the authority to determine the agenda and to draft the amendments to be proposed should rest with the convention rather than with Congress or the state legislatures.

\section{Determining the Validity of State Applications}

If Congress and the state legislatures lack the power to limit a constitutional convention to consideration of a particular amendment or subject, the issue arises whether state applications calling for Congress to convene a limited convention are valid. Professor Charles Black argues that, "[s]tate requests for a limited convention create no obligation under Article $\mathrm{V}$, since they are not applications for the thing which, and only which, the States may oblige Congress to call."'s2 Professor Black rejects the argument that a state's request for a limited convention should be treated as an application for an unlimited convention. ${ }^{53}$

There is often a question, however, whether a state has in fact called for a limited convention. Nothing in the argument against the limitation of subject matter suggests that states may not validly recommend that a convention deal with a single subject, or that it consider a draft text of an amendment, so long as the applications do not assume that the applying state legislatures or Congress can limit the convention's agenda. For example, a state application that requests Congress to call a convention, and recommends that the convention be limited to consideration of an amendment requiring a balanced federal budget, should be deemed valid, provided it is clear that the suggested limit is only a recommendation.

50. An example of a limited convention that would involve minimal congressional control is one called for the sole purpose of repealing an earlier amendment. In that case, strict definition of the subject in state applications would preclude a convention from considering options such as a partial repeal.

51. Although it is possible to imagine a hypothetical set of legislative applications requiring a limited convention that might not as seriously implicate the concerns that animated the drafters, it is those possibilities that are most likely that should influence our interpretation of what the drafters meant by "a Convention for proposing Amendments."

52. Black, supra note 4 , at $199-200$ (emphasis in original).

53. Id. at 200. 


\section{Limited Conventions}

An application may be ambiguous on this last point. Suppose that a state legislature applies to Congress for a constitutional convention "for the purpose of" proposing an amendment, the text of which is set out in the application. The use of the phrase "for the purpose of" is not necessarily inconsistent with recognition by the applying legislature that the convention would be free to consider other amendments. Nevertheless, in light of the widespread assumption that the state legislatures and Congress can impose subject matter limits on a convention, ${ }^{54}$ the applying legislature may have assumed that the convention would be strictly limited to considering the suggested draft amendment. Before summoning a convention, Congress ought to be confident that those who applied for the convention did so with a proper understanding of the convention's authority.

State applications recently submitted to Congress, calling for a convention on a balanced federal budget, illustrate this point. With one or two exceptions, ${ }^{55}$ the thirty "balanced budget" applications are clearly premised on the assumption that a convention's subject matter can be limited by the state legislatures and Congress. At least twentytwo of the applications request Congress to call a convention "for the specific and exclusive purpose"so or "the sole and exclusive purpose"57 of proposing an amendment requiring a balanced federal budget. If Congress lacks the power to limit a convention to consideration of a particular amendment, then these applications request something that Congress cannot grant. Moreover, there is no reason to assume that every state that requested a convention for the "sole and exclusive" purpose of approving a draft amendment would wish Congress, if it could not call a limited convention, to call instead a convention free to set its own agenda.

This last point need not be left to conjecture, however; a number of state resolutions are explicit on this point, and render any debate over the proper treatment of such applications academic. The Colorado legislature, for example, in applying for a convention for "the specific and exclusive purpose" of proposing an amendment prohibiting "deficit spending," expressly resolved "that this application and request be deemed null and void, rescinded, and of no effect in the event that

\section{See note 5 supra.}

55. See, e.g., N.D. S. Con. Res. No. 4018 (1975), reprinted in 125 Conc. Rec. S1310 (daily ed. Feb. 8, 1979) (calling "for a convention for such purpose as provided by Article $\checkmark$ of the Constitution," while proposing specific balanced budget amendment).

56. See, e.g., Ala. H.J. Res. 227 (1976), reprinted in 125 ConG. Rec. S1306 (daily ed. Feb. 8, 1979) (emphasis added).

57. See, e.g., Kan. S. Con. Res. 1661 (1978), reprinted in 125 CoNG. Rec. S1307 (daily ed. Feb. 8, 1979) (emphasis added). 
such convention not be limited to such specific and exclusive purpose." 58 The applications submitted to Congress by Idaho ${ }^{50}$ and North Carolina $^{60}$ contain similar restrictions. The Utah application expresses its limitation even more precisely, resolving

that this application for a Convention Call for proposing amendments be limited to the subject matter of this Resolution and that the State of Utah be counted as part of the necessary two-thirds states for such a call only if the convention is limited to the subject matter of this Resolution. ${ }^{61}$

Thus, if Congress lacks the power to limit a convention to the exclusive consideration of a particular narrow amendment, applications such as these, now being counted as part of the total, simply self-destruct. They are obviously invalid under the test set out, as are other applications that erroneously assume congressional authority to limit a convention.

\section{The Viability of an Unlimited Convention}

If neither the state legislatures nor Congress may limit a convention's agenda, the question arises whether the only kind of convention contemplated by Article $V$ is one to revise the entire Constitution. Professor Black suggests that the convention method was designed to provide "some means of compelling a thorough reconsideration of the new plan." 62 The convention mechanism, in Professor Bruce Ackerman's view, should be reserved for those occasions "when the states are willing to assert the need for an unconditional reappraisal of constitutional foundations." "63 If conventions must propose general revisions, then Professor Van Alstyne is correct in observing that it "all but eliminates [Article V's] use in response to specific, limited state dissatisfactions." 64

There is, however, no basis in Article $\mathrm{V}$ for asserting that a convention is required to reappraise the whole Constitution, or that states

58. Colo. S. J. Mem. 1 (1978), reprinted in 125 Cong. Rec. S1306.07 (daily ed. Feb. 8, 1979).

59. Idaho H. Con. Res. 7 (1979), reprinted in 125 Cong. REc. S1932 (daily ed. Mar. 1, 1979).

60. N.C. S. J. Res. 5 (1979), reprinted in 125 Conc. Rec. SII23 (daily ed. Feb. 6, 1979).

61. Utah H.J. Res. 12 (1979), reprinted in 125 CoNG. Rec. S2363.64 (daily ed. Mar. 8, 1979).

62. Black, supra note 4 , at 201.

63. Ackerman, Unconstitutional Convention, New Republic, Mar. 3, 1979, at 8.

64. Van Alstyne, supra note 5, at 1303 . Ackerman's argument permits Van Alstyne to characterize this position as one that tells the states that they may not seek a convention for the purpose of considering the repeal of one amendment "unless they mean also to consider a repeal of the other twenty-five and of all six articles as well (and to manifest that willingness in the resolutions they submit to Congress). . ." Id. at 1306. 
would have to favor such revision before they could apply for a convention. It is reasonable to expect that a convention would choose to confine itself to considering amendments addressing the problem that led states to apply for the convention. If the prospect of a "runaway convention" 65 is frightening, ${ }^{66}$ then delegate candidates are likely to campaign for office on a pledge to limit the convention's agenda and that pledge is likely to have popular appeal. While some delegates would undoubtedly lobby to have the convention propose amendments on other subjects, such appeals would not be likely to commend themselves to a majority of the delegates. ${ }^{07}$

It is probably true that the state legislatures "would be less likely to take advantage of the convention method of amendment if they believed a convention, once convened, would be free to propose drastic changes." 0 If a convention is free to set its own agenda, there is a chance that the convention, in spite of the recommendations of the applying states, would consider subjects other than those recommended. However, a majority of delegates would have to be persuaded to support those amendments on "extraneous" subjects, and three-fourths of the states would still have to ratify them. Thus it is unlikely that delegates at the Philadelphia Convention considered this risk to be so substantial that they would have assumed that no convention would be viable unless Congress and the applying states could control its deliberations. Moreover, Congress itself was granted unlimited power to propose constitutional amendments; there is no reason why a convention, possessed of the very same authority to propose amendments, would have been viewed by the drafters as too frightening a prospect to be a practical method of proposing amendments. ${ }^{69}$

65. As Professor Black has noted, the term "runaway convention" is a misnomer. If a properly called convention is constitutionally free to exercise its own judgment about the limits of its deliberations, then "no convention can be called that has anything to run away from." Black, supra note 4, at 199. I use the term here to refer to a convention that, acting within its constitutional authority, proposes an amendment different from the amendment sought by those who requested the convention.

The California Memorandum, in arguing for the validity of applications for a limited convention, suggests that one defense against a "runaway convention" is "the enormous control that Congress can and should impose upon a constitutional convention." California Memorandum, supra note 5 , at 22 . The argument here is that such control is impermissible and is likely to be unnecessary.

66. In 1789, James Madison opposed the calling of a convention to propose a Bill of Rights, for fear that it would "turn everything into confusion." See note 47 supra.

67. But $c f$. W. Keefe \& M. Ogul, The American Legislative Process 242 (4th ed. 1977) ("logrolling" enables minority positions to gain majority support).

68. Note, supra note 5 , at 1629.

69. This point was apparently overlooked by the author of the California Memorandum, who states that if the legislatures and Congress lack the power to limit the agenda of a constitutional convention, then the convention would be an unthinkable "black hole of absolute power." California Memorandum, supra note 5 , at 16. 


\section{Conclusion}

If the legislatures of thirty-four states request Congress to call a general constitutional convention, Congress has a constitutional duty to summon such a convention. If those thirty-four states recommend in their applications that the convention consider only a particular subject, Congress still must call a convention and leave to the convention the ultimate determination of the agenda and the nature of the amendments it may choose to propose. If, however, a state's application is based on the erroneous assumption that Congress is empowered to impose subject-matter limits on the convention, such an application must be considered invalid. Many of the state applications calling for a convention on a balanced budget amendment are invalid under this test. Congress has no authority to call a convention in the absence of valid applications from two-thirds of the states. Therefore, even if the total number of applications reaches thirty-four, Congress must decline to call a constitutional convention. 